\title{
Development of Indonesian Free Trade and Port Zone: Analysis of Historical in Batam Island
}

\author{
Isdian Anggraeny $^{1 *} \quad$ Isdiyana Kusuma $\mathrm{Ayu}^{2}$ \\ 1 Faculty of Law of Universitas of Muhammadiyah Malang, Raya Tlogomas Street Number 246, Malang, \\ Indonesia \\ 2 Faculty of Law of Universitas Islam Malang, M.T. Haryono Number 193, Malang, Indonesia
}

\begin{abstract}
Batam Island is one of the areas designated as National Strategic Areas in Indonesia. The development and direction of the Government's policy towards Batam Island underwent several policy changes in each period of government that began in 1973 to the present. Therefore, the author will examine about: What is the history of the development of Batam Island as the Free Trade and Port Zone in Indonesia? It certainly aims to find out the development and direction of the Government's policy towards Batam Island and can be used as a framework in making policies and legislation on Batam Island in the future to improve its function as a national strategic area. The study of normative juridical law with the method of approach which includes: The legal approach, the concept approach, and the historical approach. The history of the development of Batam Island as a Free Trade and Port Zone in Indonesia to date has 5 periods. These periods are: 1) The preparation period; 2) The period of infrastructure development and investment; 3) Development period for infrastructure development and investment; 4) Period of improvement of facilities and infrastructure, investment and environmental quality; and 5) The preparation period for establishing Batam as a Special Economic Zone in the Free Trade and Port Zone.
\end{abstract}

Key words: Development history, Free Trade and Port Zone, Batam Island.

DOI: $10.7176 / J L P G / 99-03$

Publication date:July $31^{\text {st }} 2020$

\section{Introduction}

Batam Island is one of the National Strategic Areas which has a very important influence nationally(Peraturan Presiden Nomor 87 Tahun 2011 tentang Rencana Tata Ruang Kawasan Batam, Bintan, dan Karimun, 2011). The Government of Indonesia made specific policies and arrangements by issuing Presidential Decree Number 41 of 1973(Keputusan Presiden Republik Indonesia Nomor 41 Tahun 1973, 1973) concerning the Batam Island Industrial Region (hereinafter referred to as Presidential Decree Number 41 of 1973). Furthermore, the Government issued Government Regulation Number 46 of 2007 concerning the Free Trade and Port Zone with several changes regulated in Government Regulation Number 5 of 2011 concerning Amendments to Government Regulation Number 46 of 2007 concerning the Free Trade and Port Zone. Government Regulation Number 46 of 2007 is the basis for the dissolution of the Batam Authority and the establishment of the Free Trade and Port Zone (hereinafter referred to as BP Batam) as a replacement for the Batam Authority.

The Free Trade and Port Zone is regulated in Law Number 44 of 2007 concerning the Establishment of Government in place of Law Number 1 of 2007 concerning Amendment to Law Number 36 of 2000 concerning the Establishment of Government Regulations in place of Law Number 1 of 2000 concerning Regions Free Trade and Free Port become Laws. The meaning of Free Trade Zone and Free Port based on Article 1 number 1 is "an area within the territory of the Unitary State of the Republic of Indonesia that is separate from customs areas so that it is free from the imposition of import duties, value-added tax, sales tax for luxury goods, and excise "(Undang-Undang Nomor 36 Tahun 2000 tentang Penetapan Peraturan Pemerintah Pengganti UndangUndang Nomor 1 Tahun 2000 tentang Kawasan Perdagangan Bebas dan Pelabuhan Bebas Menjadi UndangUndang, 2000). The establishment of the Free Trade and Port Zone is carried out to encourage international trade traffic so that it can bring in foreign exchange for Indonesia so that it will eventually be able to give influence and benefit to the welfare of the Indonesian people.

The formation of the Free Trade Zone and Free Port area is characterized by various activities in the economic sector, such as the maritime trade sector, industry, transportation, banking, tourism, and other fields. The period for the existence of the Free Trade Zone and Free Port is determined by the Government Stipulation in place of Law Number 1 of 2007 for 70 years starting from being determined as a Free Trade Zone and Free Port. The function of the existence of the Free Trade Zone and Free Port is a place to develop businesses in the fields of trade, services, industry, mining and energy, transportation, maritime and fisheries, post and telecommunications, banking, insurance, tourism, and other fields. Areas that are designated as Free Trade Areas and Free Ports are Batam, Bintan, Karimun. The area is one of the National Strategic Areas and a Special Economic Zone candidate in the form of a Free Trade Zone and Free Port. The existence of Batam Island as a Free Trade and Port Zone makes Batam Island has features that are different from other regions. The specialty of Batam Island was developed to trigger an investment climate in Indonesia. 
The existence of Batam Island as one of the Free Trade Areas and Free Ports needs to be strengthened by presenting historical studies related to the history of the development of Batam Island as the Free Trade and Port Zone in Indonesia. Of course, the history of the development of Batam Island cannot be separated from various legal policies from the Government from time to time. The history of law is often interpreted as a science that describes the formation of a legal system in society. If it is neglected with the development of Batam Island, the influence of the geographical location of an area and the country's destination is also one of the formations of Batam Island as the Free Trade and Port Zone in Indonesia. Therefore, to know the development and direction of the Government's policy towards Batam Island, it is necessary to learn how the history of the development of Batam Island began in 1973 to the present. Besides, with the historical study related to Batam Island, it can be used as a framework for making policies and regulations on Batam Island. Based on the above thought, the author in this study will describe and identify: How the history of the development of Batam Island as the Free Trade and Port Zone in Indonesia. Of course, studies related to the history of Batam Island as the Free Trade and Port Zone in Indonesia have not yet been undertaken in-depth studies so the theme in this Writing is the History of the Development of Batam City as a Free Trade Zone and Free Port in Indonesia

\section{Research Methods}

This research is a normative juridical legal research because it wants to study related legal products (Soekanto \& Mamudji, 2004) related to land regulation and the development of Batam City as a Free Trade Zone and Free Port in Indonesia. Approach methods used in this study include: 1) The legislative approach, namely by examining the laws and regulations (Marzuki, 2007), relating to land regulations and the existence of Batam Island as a special area in Indonesia; 2)Conceptual approach, namely by studying and understanding the concepts (Ibrahim, 2007). Furthermore, techniques for analyzing legal materials are arranged systematically using the interpretation system, such as grammatical interpretation and systematic interpretation; and 3) Historical Approach, which is the approach taken in the framework of understanding the philosophy of the rule of law from time to time, and understanding the changes and developments in the philosophy that underlie the rule of law (Marzuki, 2007).

\section{History Of The Development Of Batam Island As A Free Trade Zone And Free Port In Indonesia}

Based on the Report of the Batam Business Entity Semester I of 2013, Batam Island is the second most crowded international shipping lane in the world after the Dover Strait in England so that Batam Island has become one of the strategic areas in Indonesia (Batam, 2013). Batam Island is near the Malacca Strait which is close to Singapore, Natuna Island and is in the middle of the Southeast Asian region. That position makes Batam Island has a special character. The special characters possessed by Batam Island, namely (Muliono, 2001):

1) Batam Island is the world's trade traffic because it is close to the Malacca Strait;

2) Batam Island is a world tourist destination, a world distribution node, a world financial center, and the land is limited, saturated with industry because it is close to Singapore;

3) The island is the world's largest gas oil field because it is near Natuna; and

4) Batam Island becomes the ASEAN Free-Trade Area because it is in the middle of the Southeast Asia Region.

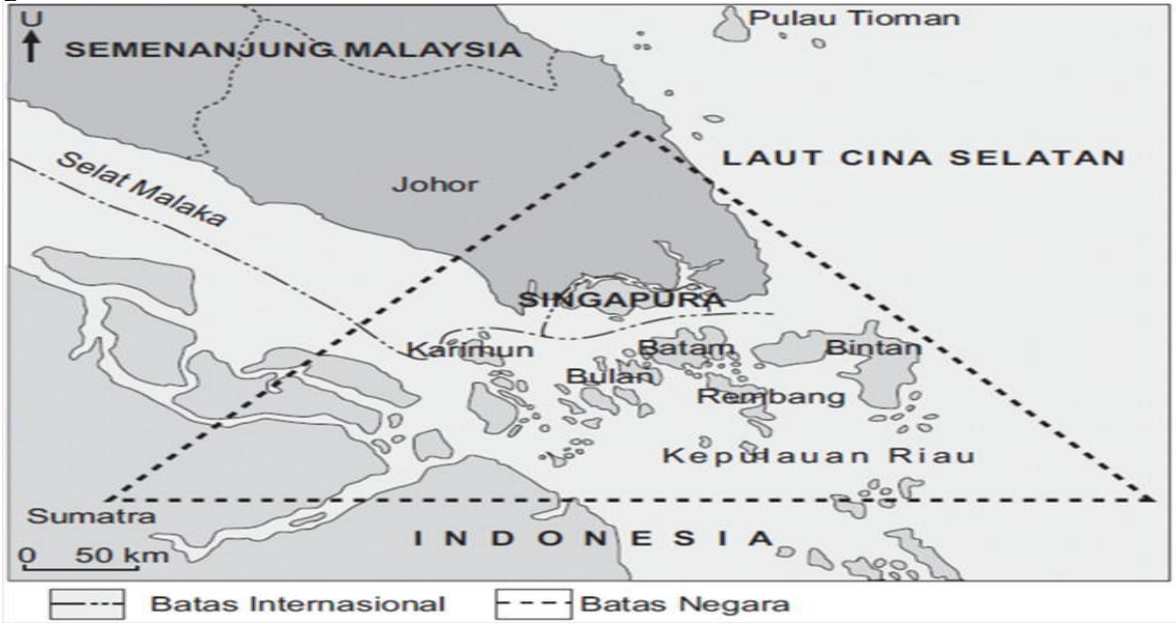

Figure 1: Map Regional Triangle Growth

The government developed Batam Island by issuing Presidential Decree Number 65 of 1970 concerning the Implementation of the Batam Island Development Project (hereinafter referred to as Presidential Decree Number 
65 of 1970).

Batam Island Development began with the idea of securing the border area so that it would not become an infiltration of a foreign power. Therefore, the Government decided to develop Batam Island as the Batam development project based on offshore oil drilling logistics through the issuance of Presidential Decree Number 65 of 1970. The stages of developing Batam Island can be divided into four periods, namely (Anggraeny et al., 2014): 1) Preparation period; 2) The period of infrastructure development and investment; 3) The period of development of infrastructure development and investment; and 4) Period of improvement of facilities and infrastructure, investment and quality of confusion. Then, this period continued with the Government's idea to make Batam Island a Special Economic Zone.

1. Batam Island Preparation Period;;

The Government issued Government Regulation Number 27 of 1968 concerning the Establishment of the National Oil and Gas Mining State Corporation (PN Pertamina). This was done to establish the National Oil and Gas Mining Company (Pertamina). This establishment aims to make Batam Island a logistics and operational exploitation and offshore oil exploration and exploration base, which was originally located in Singapore. This can be seen in the weighing section of the Decree of the President of the Republic of Indonesia Number 65 of 1970 concerning the Implementation of the Batam Island Development Project 1970 (Keputusan Presiden Republik Indonesia Nomor 65 Tahun 1970 tentang Pelaksanaan Projek Pembangunan Pulau Batam 1970, 1970) letters a and $b$.

In 1971, the President issued Presidential Decree Number 74 of 1971 concerning the Development of Batam Island Development. The issuance of this presidential decree made the Batuampar region designated as a region supporting oil exploration and exploitation industries. Subsequently, in 1972, the Batam Island Master Plan was formulated for the development of directions for the entire Batam Island and evaluation of developments that had not yet shown optimal results. Until 1973, President Soeharto stipulated Presidential Decree No. 41 of 1973 concerning the Batam Island Industrial Zone which stated that the entire Batam Island area was designated as the Batam Island Industrial Area managed by two new institutions. The agency is the Batam Island Industrial Area Industrial Enterprise Company which is tasked with organizing the industrial area exploitation. Another institution is Otorita Batam as the ruler responsible for the development and growth of the Batam Island Industrial Area and has the tasks listed in Article 4 paragraph 1) (Keputusan Presiden Republik Indonesia Nomor 41 Tahun 1973, 1973). Otorita Batam in carrying out its duties is responsible to the President and in carrying out his daily duties receive and heed the instructions given by the Batam Island Industrial Supervisory Board. In connection with the duties and responsibilities of the Batam Authority, the State grants the entire land area and the group of surrounding islands with Land Management Rights.

In 1974, based on Government Regulation Number 20 of 1972 concerning Bonded Warehouses, the Government issued Presidential Decree Number 33 of 1974 concerning the Appointment and Stipulation of SeveralBusiness Bonded Warehouse Areas in Batam Island Industrial Areas. Several Business Areas Bonded Warehouse, namely Batuampar, Sekupang, and Kabil (Keputusan Presiden Nomor 33 Tahun 1974 tentang Penunjukan Dan Penetapan Beberapa Wilayah Usaha Bonded Warehouse Di Daerah Industri Pulau Batam, 1974). Article 1 paragraph 1 of Government Regulation 31 of 1977 concerning Amendment to Government Regulation Number 20 of 1972 concerning Bonded Warehouse defines Bonded Warehouse as follows: "Bonded Warehouse is an institutional facility in the field of trade in the Indonesian customs area that has a certain business territory and special provisions in the field of customs, import, export, foreign exchange/goods, and investment, as a place to store, store, place, package, and package / or process goods from (Peraturan Pemerintah 31 Tahun 1977 tentang Perubah an Peraturan Pemerintah Nomor 20 Tahun 1972 tentang Bonded Warehouse, 1977):

a. outside Indonesian customs areas, without first being subject to customs, excise, tax and or other State levies until the goods are released for import purposes;

b. outside the Indonesian customs area, with no levies on customs duties, excise, taxes and or state levies if the goods are issued for export or re-export purposes;

c. in Indonesian customs areas, without first import duty, excise, tax and or other State levies until the goods are issued for export purposes.

2. Period of Infrastructure Development And Investment;

In 1984, the President issued Presidential Decree Number 56 In 1984, the addition of Batam Island Industrial Area Work Area and its Establishment as business Bonded Warehouse Area Based on Article 1, the scope of Batam Island Industrial Area's work area was expanded by adding five islands around Batam, namely Kasem Island, Moi-Moi Island, Ngenang Island, Tanjung Sauh Island, and Janda Berias Island (Keputusan Presiden Nomor 56 Tahun 1984 tentang Penambahan Wilayah Lingkungan Kerja Daerah Industri Pulau Batam dan Penetapannya Sebagai Wilayah Usaha Bonded Warehouse (Kawasan Berikat), 1984). The entire working areas were given bonded warehouse status.

Furthermore, the government issued Government Regulation No. 22 of 1986 about Bonded Zone. With the 
existence of this government regulation, Government Regulation Number 31 of 1977 is declared no longer valid. Furthermore, Government Regulation No. 22 of 1986 be revised with the issuance of Government Regulation No. 14 of 1990 regarding Amendment to Government Regulation No. 22 of 1986 concerning Bonded (BondedZone).This Government Regulation was then used as the basis for the issuance of Presidential Decree No. 28 of 1992 concerning Addition to the Work Area of the Batam Island Industrial Area and its Establishment as a business Area Bonded Zone. This decision expanded the working area of the Batam Island industry by adding Rempang Island, Galang, Galang Baru, and 39 other small islands. Based on Presidential Decree No. 28 of 1992, the preparation of the development plan for Rempang Island and Galang Island was carried out as a single unit and in the context of perfecting the Batam Island Industrial Area Development Master Plan stipulated by the President.

In 1995 there was a potential change in the status of Batam Island because Law No. 10 of 1995 concerning Customs was issued. With the existence of this law, the understanding of Batam as a Bonded Zone has changed due to the issuance of Government Regulation Number 33 of 1996 concerning Bonded Storage Places. The definition of bonded zones in Government Regulation Number 33 of 1996 is different from the understanding of bonded zones in Government Regulation Number 14 of 1990 . With this change in understanding, there has also been a change in procedures for the entry and exit of goods from and to Batam Island and the separation of industrial and warehousing areas with other region.

3. The Period of Development of Infrastructure Development And Investment;

The period of development of infrastructure development and investment is more focused on people's welfare and improvement of the investment climate. On January 15, 1998, the President signed a Memorandum of Economic and Financial Policies with the International Monetary Fund (IMF), which included a plan to remove tax exemptions from Batam. This is stated in Government Regulation No. 39/1998 concerning the Treatment of Value Added Tax and Sales Tax on Luxury Goods in the Bonded Zone of the Batam Island Industrial Region which began to take effect in April 1, 1998. However, this provision has not yet been operated on Batam Island. Until the end of 2000, the status of Batam was still floating with the Government Regulation Number 39 of 1998. While on the other hand there was an intention to determine the status of free-trade and ports for Batam so that the consequences were free of tax on goods. For the investment world, these changes reflect uncertainty. To develop properly, Batam requires clear and consistent legal status.

Finally, in 2000 Law No. 36/2000 was issued concerning the Establishment of Government Regulations instead of Law No. 1/2000 concerning Free Trade Areas and Free Ports into Laws. This Law was issued against the background of the assessment that a free trade area and port can encourage international trade traffic activities that bring in foreign exchange for the State and can have a major impact and benefit for Indonesia, to be able to open employment as wide as possible, increase tourism, and foreign and domestic investment (Undang-Undang Nomor 36 Tahun 2000 tentang Penetapan Peraturan Pemerintah Pengganti Undang-Undang Nomor 1 Tahun 2000 tentang Kawasan Perdagangan Bebas dan Pelabuhan Bebas Menjadi Undang-Undang, 2000).

The follow up of the issuance of Law Number 36 of 2000 is the issuance of Government Regulation Number 63 of 2003 concerning the Treatment of Value Added Tax and Sales Tax on Luxury Goods in the Next Region (Bonded Zone) of Batam Island Industrial Area as amended by Government Regulation Number 30 of 2005. Furthermore, to support a consistent and legal investment climate in Batam Island, Bintan Industrial Estate and Karimun Industrial Cooperation Areas, the Government issued the Minister of Finance Regulation of the Republic of Indonesia Number: 60 / Pmk.04 / 2005 Regarding Bonded Piling Places on Batam Island, Bintan, and Karimun.

4. Period of Improvement of Facilities And Infrastructure, Investment, and Environmental Quality

This period of improvement of facilities and infrastructure is marked by the issuance of Law Number 40 of 2007 concerning the Establishment of Government Regulations instead of Law Number 1 of 2007 concerning Amendments to Law Number 36 of the Year 2000 Regarding the Establishment of Government Regulation instead of Law Number 1 of 2000 concerning Free Trade Zones and Free Ports Becoming Laws. With the provisions of Article 4, the Government shall immediately issue Government Regulation Number 46 of 2007 concerning the Free Trade and Port Zone because Batam and the surrounding small islands have met the criteria to be stipulated as Free Trade and Free Port Areas. Subsequently, Government Regulation No. 46 of 2007 was revised with many changes listed in Government Regulation No. 5 of 2011 concerning the amendment to government regulation No. 46 of 2007 concerning the Free Trade and Port Zone.

Amendment to Government Regulation No. 46 of 2007 occurred because BP Batam encountered obstacles in carrying out the management, development, and development of Batam Island which were stipulated by Government Regulation No. 46 of 2007, specifically in the matter of transferring assets and employees of Otorita Batam to BP Batam and BP Batam's financial management. To this Government Regulation Number 5 of 2011 also stipulates that the Management, development, and construction of the Free Trade and Port Zone are carried out by the Head of the Free Trade and Port Zone Exploitation Agency (Article 2A paragraph (1)). 
Besides, with the increase in business activities, it is necessary to expand the determination of the Free Trade Zone and Free Port which includes the Widowed Berias and its cluster.

5. The Preparatory Period For The Designation Of Batam As A Special Economic Zone In The Free Trade And Port Zone

Around 2006, Batam has been comprehensively reviewed about the readiness to be designated as a Special Economic Zone (Hadiyati, 2019) until finally this plan is further reviewed by the Coordinating Ministry for Field Affairs The economy together with the Free Trade and Port Zone Council (Lavinda, 2018). However, not all areas on Batam Island become Special Economic Zones, which is different from the Free Trade Zone and Free Port, which applies to all major islands in Batam Island (Lavinda, 2018). Special Economic Zones have been regulated by the Government by issuing the Special Economic Zones Law in 2009 and implementing regulations, namely the Government Regulation in 2015 concerning Facilities and Facilities in Special Economic Zones. Special Economic Zones are zones with certain limits within the jurisdiction of the Unitary State of the Republic of Indonesia that are designated to carry out economic functions and obtain certain facilities (Article 1 Paragraph 1 of the Special Economic Zones Law (Undang-Undang Nomor 39 Tahun 2009 tentang Kawasan Ekonomi Khusus, 2009)). Through a General Explanation of Government Regulations on Facilities and Facilities in Special Economic Zones, it is stated that the development of Special Economic Zones is intended to accelerate the development of a national economy based on economic democracy with the principles of togetherness, equitable efficiency, sustainability, environmental insight, independence, and by maintaining a balance of progress and national economic unity (Peraturan Pemerintah Republik Indonesia Nomor 96 Tahun 2015 Tentang Fasilitas dan Kemudahan di Kawasan Ekonomi Khusus, 2015). The formation of Special Economic Zones established and determined by the Government must meet the requirements to have geoeconomic and geostrategic advantages to maximize industrial activities, exports, imports, and other economic activities that have high economic value as regulated in Article 2 of the Special Economic Zones Law (Undang-Undang Nomor 39 Tahun 2009 tentang Kawasan Ekonomi Khusus, 2009).

With the plan to establish Special Economic Zones in several Batam Island Regions, it is expected to be able to increase investment in special economic zones that can support national economic development and economic development in certain regions and increase employment, need to provide facilities and facilities in special economic zones as regulated Article 2 of the Government Regulation on Facilities and Facilities in Special Economic Zones (Peraturan Pemerintah Republik Indonesia Nomor 96 Tahun 2015 Tentang Fasilitas dan Kemudahan di Kawasan Ekonomi Khusus, 2015) in the form of taxation, customs, and excise, traffic of goods, employment, immigration. The Head of the BP Batam, Eddy Putra Irawadi, stated that there are two Special Economic Zones in Batam soon to be inaugurated, namely the Hang Nadim Logistics Airport Special Economic Zone (as a regional hub for e-commerce trading for products and platforms) and the Nongsa Special Economic Zone Digital Park (as a means to serve the needs of the digital economy and start-up in Batam) (Jpnn.com, 2019). However, the central government is currently completing government regulations that will become the legal umbrella for the determination of the two special areas (Jpnn.com, 2019). The establishment of this Special Economic Zone is to maximize the economic potential on Batam Island which remains a Free Trade and Port Zone with all its tax-free facilities. This was also stated by Bacharuddin Jusuf (BJ) Habibie who assessed that the Free Trade and Port Zone was still the best for Batam (Jpnn.com, 2019).

\section{Conclusion}

History of the development of Batam Island as a Free Trade and Port Zone in Indonesia to date there are 5 periods. These periods are: 1) The preparation period; 2) The period of infrastructure development and investment; 3) The period of development of infrastructure development and investment; 4) Period of improvement of facilities and infrastructure, investment and quality of the environment; and 5) The preparation period for establishing Batam as a Special Economic Zone in the Free Trade Zone and Free Port. The development of Batam to date is based on the Government's desire to Maximize the Potential of Batam which is one of the regions that have a very important influence and is designated as a National Strategic Region in Indonesia. To support this potential, the Government has taken many strategic actions that are always based on laws and regulations as the foundation of Batam to maximize its potential.

\section{References}

Anggraeny, http://hukum.studentjournal.ub.ac.id/index.php/hukum/article/view/689. Jurnal Hukum.

Batam, D. P. and I. S. C. of B. (2013). Laporan Badan pengusahaan Batam Semester I tahun 2013.

Hadiyati, N. (2019). MEMAHAMI PROBLEMATIKA HAK PENGELOLAAN TANAH KOTA BATAM

Dalam Rangka Penetapan Batam sebagai Kawasan Ekonomi Khusus. Yurispruden, 2(1), 51-65. http://riset.unisma.ac.id/index.php/yur/article/view/1660

Ibrahim, J. (2007). Teori dan Metodologi Penelitian Hukum Normatif. Bayumedia. 
Jpnn.com. (2019). Dua Kawasan Ekonomi Khusus di Batam Segera Diresmikan. Www.Jpnn.Com. https://www.jpnn.com/news/dua-kawasan-ekonomi-khusus-di-batam-segera-diresmikan

Lavinda. (2018). Pengusaha Tolak Batam jadi Kawasan Ekonomi Khusus. CNN Indonesia. https://www.cnnindonesia.com/ekonomi/20180604085527-92-303165/pengusaha-tolak-batam-jadikawasan-ekonomi-khusus

Marzuki, P. M. (2007). Penelitian Hukum. Kencana.

Muliono, H. (2001). Merajut Batam Masa Depan: Menyongsong Status Free Trade Zone. Pustaka LP3ES Indonesia.

Keputusan Presiden Republik Indonesia Nomor 65 Tahun 1970 tentang Pelaksanaan Projek Pembangunan Pulau Batam 1970, Pub. L. No. 65 (1970).

Keputusan Presiden Republik Indonesia Nomor 41 Tahun 1973, Pub. L. No. 411973 (1973).

Keputusan Presiden Nomor 33 Tahun 1974 tentang Penunjukan Dan Penetapan Beberapa Wilayah Usaha Bonded Warehouse Di Daerah Industri Pulau Batam, Pub. L. No. 33 (1974).

Peraturan Pemerintah 31 Tahun 1977 tentang Perubah an Peraturan Pemerintah Nomor 20 Tahun 1972 tentang Bonded Warehouse, Pub. L. No. 31 (1977).

Keputusan Presiden Nomor 56 Tahun 1984 tentang Penambahan Wilayah Lingkungan Kerja Daerah Industri Pulau Batam dan Penetapannya Sebagai Wilayah Usaha Bonded Warehouse (Kawasan Berikat), Pub. L. No. 56 (1984).

Undang-Undang Nomor 36 Tahun 2000 tentang Penetapan Peraturan Pemerintah Pengganti Undang-Undang Nomor 1 Tahun 2000 tentang Kawasan Perdagangan Bebas dan Pelabuhan Bebas Menjadi UndangUndang, Pub. L. No. 36 (2000).

Undang-Undang Nomor 39 Tahun 2009 tentang Kawasan Ekonomi Khusus, (2009).

Peraturan Presiden Nomor 87 Tahun 2011 tentang Rencana Tata Ruang Kawasan Batam, Bintan, dan Karimun, Pub. L. No. 87 (2011).

Peraturan Pemerintah Republik Indonesia Nomor 96 Tahun 2015 Tentang Fasilitas dan Kemudahan di Kawasan Ekonomi Khusus, Pub. L. No. 96 (2015).

Soekanto, S., \& Mamudji, S. (2004). Penelitian Hukum Normatif Suatu Tinjau Singkat (8th ed.). Sinar Grafika.

Isdian Anggraeny, was born in Batam, February 9th, 1989, completed the undergraduate degree from Faculty of Law at University of Brawijaya in 2011, and graduated master degree from program Master of Notary at Brawijaya University in 2014. She currently works as a lecturer at the Faculty of Law, Muhammadiyah Malang University. The author can be contacted by email: isdian@umm.ac.id

Isdiyana Kusuma Ayu, was born in Batam, August 10th 1991, completed the undergraduate degree from Faculty of Law at University of Brawijaya in 2013, graduated master degree from Graduate Program, concentration of Master of Notary at University of Brawijaya in 2015. She currently working as a Lecturer at the Faculty of Law, Universitas IslamMalang. The author can be contacted by email: isiyana@unisma.ac.id 